\title{
Santa Evita. Historia, ficción y mito. Una narrativa a partir del otro lado
}

\author{
Santa Evita. H istory, fiction and myth. A narrative \\ from another side
}

\author{
MARCELO CODDOU \\ D rew University, M adison, N ew Jersey, EE.UU . \\ E-mail: mcoddou@drew.edu
}

\section{RESU MEN}

En Santa Evita, Tomás Eloy M artínez recepciona una variedad amplia de discursos y re escribe el mito de Evita, renovándolo en una "ficción verdadera". En tal proceso imaginario revivifica lo que se había cosificado haciéndole re-encontrar su fuerza impulsora de nuevos procesos de desarrollo histórico. Recuperando la esencia mítica de un personaje central de la historia argentina, logra negar su musealización, su neutralización y despolitización. La "verdad" que se pretende establecer queda enmascarada en las "mentiras" de la ficción.

Palabras claves: $M$ ito, historia, ficción, paratexto, efecto de realidad, transfiguración, discurso figurativo, ficción verdadera.

\begin{abstract}
ABST RACT
In Santa Evita, a narrative in which fiction and the pretended truths of historiography are challenged, Tomás Eloy M artínez uses a wide variety of discourses to re-write and give new life to the mith of Evita Perón. In thisintellectual endeavor that combines imagination and historical facts ("real fiction") M artínez breathes new life into and sheds new light on what had became a stale myth, a "museum piece" of argentinian history, questioning Santa Evita in an effort to give voice to meanings previously silenced.
\end{abstract}

Keywords: M yth, historiography, fiction, figurative discourse, real fiction.

Recibido: 28-08-2007. Aceptado: 12-10-2007. 
SI LA INTEN CION deTomás Eloy M artínez (TEM ) es abarcar la realidad de Sla Argentina, lo hace concordando plenamente con lo que afirmara muchas veces su admirado amigo, Gabriel García M árquez:

La realidad no sólo es los policías que llegan matando gente, sino también las mitologías, las leyendas, todo lo que forma parte de la vida de la gente, y todo eso hay que incorporarlo (G onzález Bermejo, 1971).

Y es en su incorporación de mitologías y leyendas en torno a Perón y Evita, que irrenunciablemente forman parte de la vida de los argentinos, como T EM se sitúa en la esfera de ficción narrativa que Vargas Llosa observara a poco de emerger einstaurarse lo que llegaría a conocerse como "la nueva novel a latinoamericana" ${ }^{1}$ y que, con variables de mucha índole, sin duda continúa siendo una de las expresiones literarias mayores de nuestra América:

H oy nuestros novelistas ya no se esfuerzan por expresar una realidad, sino visiones y obsesiones personales: su realidad. Pero los mundos que crean sus ficciones y que valen ante todo por sí solos, son, también, versiones, calas a diferentesniveles (psicológicas, fantásticaso míticas) deAmérica Latina(Vargas Llosa, 1969: 31).

Y es precisamente a todos esos niveles que apuntan las novelas deT EM . EI psicológico juega papel primordial no tan sólo en sus obras alejadas de un prevaleciente componente político -Sagrado, La mano del amo-, sino también en La novela dePerón, Santa Evita y, sin dudas, en El vuelo dela reina y en EI cantor detango. Lo fantástico - quehabría que entender en el sentido que el menciona-

\footnotetext{
${ }^{1}$ M e parece pertinente reconocer aquí el acerto de John S. Brushwood, no siempre tenido en cuenta cuando se trata no sólo de describir sino de valorar y jerarquizar lo acontecido con la así Ilamada nueva narrativa hispanoamericana. Sostuvo el estudioso, a seis años de las afirmaciones de Vargas Llosa:: "Although the terms new Latin American novel and the boom sometimes appear synonimous, they really indicate two different aspects of a single phenomenon -the maturity of fiction in Latin America" (1975: 211). Luego propone datar en losfinales dela década delos cuarenta el momento en que comienza a reafirmarse la narrativa continental, y que encuentra un cambio de apreciación en los años siguientes a Pedro Páramo, cuando se produce un interés internacional sin precedentes por los novel istas hispanoamericanos en los años sesenta, momento de un incremento espectacular en el número de novelas dealtísima calidad y que vendría a ser calificado, demodo muy discutible, como boom (1975). D el boom son continuadores legítimos todos los mencionados por Angel Rama en su libro La novela latinoamericana. Panoramas 1920-1980, y los que en M éxico, Argentina, Chile y otros países continúan ofreciendo obras de valor indisputable, reconocido no sólo por los lectores cultos, sino también por el público masivo.
} 
do Vargas L losa otorga al término- es dominante en Santa Evita, novela en que sin embargo es lo mítico lo que se ofrece como constituyente decisivo de su cosmos narrativo.

Privilegiar una u otra esfera en la lectura analítica es, sin duda, válido. M as menospreciar el complejo totalizanteresulta, obviamente, reductor. Lo quequiero proponer, entonces, es que la obra de TEM nos exige atender a los muchos niveles a que ella apunta. Todo intento esquematizador setopa con la riqueza de sus propuestas y plasmaciones. No por nada el escritor argentino ha buscado escaparse de los limitantes marbetes taxonómicos. Por ejemplo: ¿"peronista" su obra? 0 ¿"antiperonista"? ¡N o! - diceél: "de un peronólogo". ¿N ovelas "históricas" las suyas? Claro, pero con todo lo que habría que matizar en una categoría peligrosamente expuesta a ser reducida a esquemas. Por eso él prefiere hablar de novel as sobrela historia. La dimensión mítica - que es la que en este estudio nos interesa revisar- opera en direccionesqueno son las deun Asturias, un C arpentier o un Arguedas, puesto queel mundo en queseda-tan diverso al del indigenismo del guatemalteco o el peruano y de la negritud cubana-, se fue construyendo más allá y más acá de esa realidad latinoamericana, de muy escasa presencia - no hablo de ausencia- en la Argentina.

G erard G enette denomina paratexto a la vía de acceso al texto, a la que define como una gran zona indecisa entre un adentro y un afuera, donde se mezclan los códigos sociales que rigen el "afuera" del texto con los códigos productores que regulan su "dentro". Esta mezcla, puntualiza el narratólogo francés, implica y significa siempre una transacción donde se deciden las estrategias y protocolos de recibimiento por los quese acogerá al texto en la sociedad (1987: 7-8). Resulta así quela aparición (social) del texto se cumple siempre de modo condicionado: a su lectura se anticipa una pre-lectura, realizada con conciencia más o menos plena, que los conocedores del autor y/o de su complejo contorno literario, social, político, etc., harán de su escrito en función, precisamente, de los paratextos.

Enfrentados a Santa Evita (1996a), nos gustaría atender a esos aspectos de modo tal que nuestras reflexiones se cumplan más allá de los procedimientos paratextuales internos (título, dedicatoria, epígrafes, reconocimientos) para abarcar también parte de los externos. La recepción paratextual externa que podría haber condicionado la lectura de Santa Evita obedece a muchos factores. El primero - quizás el más importante : la asunción "en serio" que seguramente iba a hacerse del discurso dirigido a una figura histórica sobre la que al parecer no cabía sino asumir actitudes extremas, despectiva o laudatoria: prostituta 0 
santa. Esto fue lo que llevó al autor, según él mismo ha declarado, a exigir que sus editores pusieran bajo el título la denominación literaria genérica: novela. TEM sabía, cómo no, que todo lo que su texto dijera sobre Eva D uarte encontraría un contexto socio-político y escritural ya establecido. Por eso quiso exigir que la recepción de lo por él escrito fuera la que había decidido su voluntad autorial. El mundo narrado en Santa Evita es, definitivamente, ficticio ${ }^{2}$. H asta un punto tal que, como lo atestigua el novelista, en su obra hay sólo un hecho narrado que se corresponde totalmente con el referente: es el capítulo final en que se cuenta cómo llegaron a manos del autor los principales materiales e informaciones sobre la suerte del cadáver de Evita (M ora, 2002).

Esta génesis inmediata de la novela -no la más profunda, claro está, y a la que también nos referiremos- la ha contado TEM en más de una ocasión en algunas de las muchas entrevistas que sele han hecho. Relata que en el invierno de 1989 se le presentaron tres militares afirmándole que conocían la verdad sobre el cadáver de Evita. Como en esos mismos momentos había una gran polémica con los historiadores argentinos por su libro anterior, La novela de Perón, que suscitó un debate sobre los derechos de los novelistas a modificar la historia oficial ${ }^{3}$, antes de comenzar Santa Evita, escribió la novela lírica La mano del amo, lo que demostraba y a él mismo lo convencía, de que "era capaz de la diversidad y de que no [se] iba a convertir inmediatamente en peronólogo" (son palabras suyas). Pero poco después - La mano del amo es de 1991- dice que le volvió la preocupación por Evita, en cuya historia establecida detectó puntos oscuros, por lo que se le ocurrió "narrar una historia ficticia con las técnicas del periodismo". Para poder escribirla setomó un año sabático en Rutgers U niversity, dondeera profesor. El escritor cuenta: "M i mujer memantenía con sus clases: la Ilamó la beca Santa Evita". Estaban Ilenos de deudas (le debían 10.000 dólares al editor de Seix Barral) y cuando terminó de escribirla se dijeron: "si al menos nos al canzara para pagar... ". N o sabían - no podían saberlo- que la novela iba a convertirse en uno de los mayores best sellers de la literatura argentina, traducida ya a treinta y seis lenguas.

\footnotetext{
2 Este proyecto, y su realización, nos hace ver a Santa Evita próxima a lo que Luis C osta Lima llama "una narrativa concebida y creada, siempre, a partir del otro lado". D efineel crítico brasileño: "Io que llamamos narrativa a partir del otro lado significa que el autor simula hablar de los percepta, para en verdad, construir una narrativa toda ella concebida por la focalización desde lo imaginario. Ahora bien, por supuesto, es innecesario insistir que esta tematización no excluye la realidad material e histórica. Recusa, eso sí, la documentalidad" (1986: 179).

3 Sobre esto léanse, del mismo TEM, sus ensayos "Ficción e historia en La novela de Perón" (1998), "H istoria y ficción: dos paralelos que se tocan" (1996c), "M ito, historia y ficción: idas y vueltas" (1996d).
} 
Volvamos a ese año 1989 en queTEM se entera de "la verdad sobre el cadáver de Evita". Transcribo la reconstitución de lo narrado por él al semanario N oticias, tal como éste lo publicó 4 :

En una turbia medianoche de invierno de 1989 sonó el teléfono en la casa de San Telmo deTomás Eloy, que decidió atender "por letargo o por desconcierto". Era el coronel H éctor A. C abanillas (en la novela se llama Tulio Ricardo Corominas), era el hombre que había pivoteado, por expresa disposición de Pedro Eugenio Aramburu, el "O perativo Traslado" de los restos de Eva Perón a lugar seguro. Cabanillas había tenido un predecesor frustrado y demencialmente castigado por la obsesión de Evita: el teniente coronel Carlos M oori Koenig (en la novela aparece con su nombre real). M oori K oenig nunca pudo dar cristiana sepultura al cuerpo de la segunda esposa de Perón. U na cadena de enigmáticas desgracias lo derrotaron antes y lo ahogaron en un río de ginebra y de delirio. Esa noche, la del Ilamado, fue una noche de cita. Tomás Eloy fue al caféTabac de Libertador y Coronel Díaz. Y allí se encontró con Cabanillas (Corominas); con Jorge Rojas Silveyra, embajador en España en los tiempos deAlejandro Agustín Lanusse. Rojas fueel encargado de devolver a Juan Perón el cuerpo de su mujer después de décadas de secretos ambulatorios. También estaba otro testigo crucial, fantasmagórico y desdoblado, que la cautela del novelista decidió llamar "M aggi". Ellos le entregaron toda la documentación que tenían en sus manos, porque "el secreto los ahogaba". La historia del cuerpo de Evita empezaba a develarse.

Aclarada la génesis externa de la novela, procuremos acercarnos a al gunos de los problemas que su lectura suscita a una reflexión crítica. Lasnovelas deTEM , tal como ellas se presentan a esta modalidad de lectura, y según fueron elaboradas de acuerdo a unos presupuestos claramente establecidos por su autor, en definitiva niegan la distinción que, según $\mathrm{H}$ yden White, existe entre las historias "históricas" y las "ficcionales" y que consistiría en que el contenido de las primeras son "los hechos reales, hechos que sucedieron realmentey en la segunda son hechos imaginarios, inventados por el narrador" (1987: 42).

TEM postula, y realiza en su obra, lo que con respecto al efecto de realidad ha sostenido Barthes:

$\mathrm{H}$ ay que descartar las afirmaciones relativas al realismo de la narrativa (... ) La función de la narrativa no es representar, es construir un espectáculo (... L La narrativa no muestra, no imita. "Lo que tiene lugar" en una narrativa desdeel punto referencial (realidad) es literalmente nada, "lo que sucede" es sólo lenguaje (1970:43).

${ }^{4}$ El relato íntegro está disponibleen la página www.literatura.org/T EM artinez/Santa_Evita.html. 
Para Barthes la estructura narrativa es reveladora de queel discurso histórico - el de la historiografía, como modo de representación narrativa- es una de las formas deelaboración ideológica o imaginaria, y llama la atención el hecho deque la estructura narrativa que surgió originalmente de la caldera de la ficción devino en la historiografía tradicional, tanto el signo como la prueba de realidad.

Al igual que el teórico francés, TEM cuestiona tanto la distinción tajante entre lo histórico y lo ficticio, como la presunción de objetividad de la historiografía que se ofrece en los modos de representación narrativos. Vale decir, los discursos no son para él meros vehículos para transmitir un contenido: ellos producen significados.

La narración realiza el tránsito del acontecimiento al discurso $0^{5}$ por un procedimiento tropológico, que TEM Ilama transfiguración y al que White define como un desplazamiento de los hechos a las ficciones literarias, en donde la transición se efectúa mediante un proceso de transcodificación.

TEM seenfrenta a la idea establecida de que a la verdad se llega sólo por medio de la objetividad científica, adscribiéndose al pensamiento de quienes sostienen que lo verdadero también puede transmitirse por medio de discursos figurativos, los propios dela ficción literaria y quetambién son de la narración historiográfica y mitológica. Al igual que Barthes, piensa que las ficciones (no sólo las "verdaderas", pero sobre todo ellas) son más que un mero medio para proporcionar información: representan el significado de los acontecimientos, lo que se logra con la simbolización $n^{6}$. En términos suyos, refiriéndose a lo que en la actualidad está haciendo la historia - entendida como historiografía- con la literatura:

La "nouvelle histoire" o "intellectual history" ha adoptado las herramientas técnicas y las tradiciones narrativas de la literatura para hacer a su modo la historia tradicional (...) Cuando digo que la novela sobre la historia tiende a reconstruir, estoy diciendo también que intenta recuperar el imaginario y las tradiciones culturales de la comunidad y que, luego de apropiárselas, les da vida de otro modo (... ) La ficción crea otra realidad y, a la vez, renueva el mito. Forjamos imágenes, esas imágenes son modificadas por el tiempo y al final no importa ya si lo que creemos que fue es lo que de veras fue (1996b).

Y no resulta extraño que el género privilegiado sea el de la novela, lo que se entiende bien si se tiene en cuenta el concepto de Bajtín de que ella es un

\footnotetext{
${ }^{5}$ Exactamente lo mismo acontece en otros sistemas de representación de la realidad: el mito, el relato historiográfico, a los queT EM se ha referido en varios ensayos suyos.

${ }^{6} \mathrm{O}$ bra, la deTEM, que ha de entenderse como acto simbólico enfocado directamente hacia "el gran discurso colectivo y de clases en el cual un texto es poco más que una parole individual o una utterance" (Jameson, 1981: 76-77).
} 
macrogénero en el que están contenidos otros géneros y que tiene la capacidad de decir la verdad por medio de su discurso figurativo7. La ficción concebida entonces en su aptitud para mostrar en toda su complejidad una realidad que otros discursos (el historiográfico, el dela biografía no novelesca, el dela ensayística de orientación psicológica, social o política, el del reportaje periodístico tradicional) no alcanzan a diseñar como definitivamente verdadera, aunque aś programáticamente lo postulen. El novelista, escritor "con licencia para mentir", como suele destacar TEM , puede hacer uso de todos esos discursos y en su entrecruzamiento encontrar cómo darle vida a la verdad que se busca establecer y que no es nunca definitiva (en La novela de Perón leemos: "Esa pasión de los hombres por la verdad me ha parecido siempre insensata" (1993: 49). Por eso: "no importa ya si lo que creemos quefuees lo que de veras fue" (Eloy M artínez, 2004).

Retengamos también lo dicho por TEM acerca de que la novela histórica ("sobre la historia", precisa el autor) por un lado "reconstruye recuperando el imaginario y las tradiciones culturales"; por otro, "dándole vida de modo distinto" y con ello "renueva el mito". Todos los términos son decisivos si se quiere entender hacia dónde se dirige el tipo de novela que este escritor produce: lo hace reconstruyendo la realidad que los documentos pretenden ofrecer como verdadera. Los instrumentos serán la imaginación recreadora y el lenguaje forjador de imágenes, con lo cual se renueva el mito. Atendamos a esto último en Santa Evita.

Es muy bien sabido que desde sus orígenes la historia y la literatura estuvieron unidas por el mito. El historiador M ario Cancel explica tal hecho aś:

Lo que daba unidad a aquellos géneros era el fondo mítico que estructuraba la visión del mundo del ser humano. D etrás del deseo de "ordenar" la realidad circundante en un todo coherente estaba también la necesidad de saber cómo las cosas llegaron a ser (... ) Por eso la historia se compenetraba con el mito y tomaba ese cuerpo literario que le permitió convertirse en un instrumento de poder, en un mecanismo útil para justificar las estructuras políticas, aunque difícilmente hubiera podido convertirse en lo contrario (1995: 45).

El que un mito cuente la historia, o sea parte significativa de ella, tiene una gran trascendencia cuando se trata de la historia de una nación o de un momento significativo de ella. TEM encuentra vigente la apreciación mítica que de Evita tenía el pueblo argentino. Lo que él hace es recoger ese mito, atendiendo a componentesfundamentales suyos, y contribuir, con su reelaboración, a man-

\footnotetext{
7 Bajtín (1998), sobre todo el capítulo "El problema de los géneros discursivos".
} 
tenerlo vivo. Proponiéndoselo o no, magnifica aquello ya existente, con lo cual selogra producir una identificación cabal de la figura de la Santa Evita por parte de quienes creen en ella con veneración y de la otra Evita que ven los que la demonizan. También logra actualizar el mito al relacionarlo con la lucha política entablada durante el largo periodo de presencia activa del peronismo. Argentina vivió - ¿vive?- doshistorias: una deaceptación plena de la dimensión mítica de la defensora de los descamisados y otra que impugna tal aceptación para, en las antípodas, reducirla con los peores calificativos. Unosy otros usan el mito de Evita en sus pugnas por el poder.

La apropiación del mito en Santa Evita tieneun sentido que nos parecemuy claro: relativizar las historias oficiales de tantos ensayos -y ficciones- que se han escrito sobre el personaje real y proponer una nueva versión, queincluirá, según decimos, los modos de apreciación de grupos sociales y políticos de la misma figura. Re-elabora relatos con los cuales un contingente significativo de argentinos se identifica y que les da, o confirma, un sentido a su existencia. Todo relato mítico, toda narración de tal dimensión, toca de al guna manera al receptor, que se siente así parte del pasado que se le narra, pues le da seguridad a sus propias creencias y concepciones, otorgándole un sentido de pertenencia a una comunidad que comparte o contrasta las mismas apreciaciones del hacer de sus héroes 0 anti-héroes. El mito, al revés de la historia, que se distancia con frialdad 0 serenidad "científica" de los personajes, permite la acción de lo imaginario y produce un relato con el cual esos sectores de la comunidad podrán identificarse. El pueblo peronista mira la historia de Evita como su historia, cuando ella es contada en todo su poderío mítico. No estoy afirmando queTEM haya pensado en ceder a las exigencias de determinados lectores - sabemos que él sostiene que un escritor, a diferencia del periodista, no debe tener nunca en cuenta el para quién se escribe-, pero sí estimo que, al respetar la dimensión mítica de Evita, pudo crear un personaje literario - esa entidad ficticia que es todo personaje novelesco- quellega a sus lectores como éstos (acepten o no la validez de tal concepción) saben que es vivido el personaje histórico que sirvió de referente al ficticio. En sus ensayos sobre Eva Perón, TEM toca con distancia crítica ese componente mítico suyo, pero en la novela aparece plenamente encarnado.

Y el mito de Eva Perón es complejo, por lo que habrá que ver cómo lo renueva la novela deTEM. Pensamos que lo hace desarticulando los elementos que más marcadamente componen ese mito. Al igual de lo que acontecía en La novela de Perón, Santa Evita se compone de varios discursos que se imbrican, yuxtaponen, cruzan y fecundan: a las reflexiones metaliterarias que recurren en toda la obra, se suman e integran relatos de vidas ficticias que tienen referentes reales (el más importante es el referido al coronel Carlos M oori K oenig y junto 
a él el de muchos otros), y la ficcionalización medular sobre las investigaciones que buscaban informarse del destino del cuerpo embalsamado. A todo ello se agrega el escrutinio y comentario de parte significativa de los escritos sobre el tema:

En Santa Evita intenté recuperar la esencia mítica de un personaje central dela historia argentina reuniendo en un solo texto todo lo que los argentinos hemos imaginado y sentido sobre Eva Perón durante dos o tres generaciones (1996b).

$Y$, en efecto, en ella se recogen escritos de Rodolfo Walsh, Julio Cortázar, Borges, Perlongher, Ezequiel M artínez Estrada, entre muchísimos otros. TEM recepciona, entonces, una variedad amplia de discursos y re-escribe -el autor sabe que la suya es una re-escritura más, no la definitiva- el mito (los mitos) de Evita, renovándolo. Su narrador reconoce que está "armando un rompecabezas", consciente que hace una historia que es literatura, ficción, pero ficción verdadera. Lo que la historiografía mostró como su impotencia, quizás pueda darlo la novela. El vacío, el silencio de la historia frente al cuerpo de Evita, será Ilenado, hablado, con la palabra de lo imaginario. H asta que aparezcan otras renovaciones del mismo mito...

El mito deEva Perón tiene sus elementos progenitores en los relatos sobre su origen oscuro, la muerte prematura (como Cristo, como el Che), sus "milagros", la momia profanada. Pero hay que actuar con precaución ante lo que sucedió con estos mitos después de la muerte de Evita, si se quiere entender tanto lo que Sebreli ha llamado su cosificación, como lo queTEM ha hecho en su novela al revivificarlo. Sebreli en su obra clásica Eva Perón zaventurera o militante? nos ha permitido ver, y cito en extenso, que:

El mito de Evita como expresión simbólica de los anhelos de justicia e igualdad de las mujeres y los trabajadores argentinos, sólo a medias realizados en la realidad, y a la vez como expresión del temor por la pérdida de sus privilegios por parte de las clases burguesas, fue como tal un mito de carácter dinámico, cread or y progresivo, estaba dirigido hacia el futuro y no hacia el pasado, como los regresivos. Pero después de la muerte de Evita comenzó el proceso de cosificación del mito, la tendencia a convertir la imagen del mito en algo fijo e inamovible, esencia eterna de un pueblo ahistórico, estático y sin desarrollo (1971: 109).

TEM no permite que el mito se vuelva regresivo: proponiéndoselo o no, lo hace recuperar su fuerza impulsora de nuevos procesos de desarrollo histórico. Su renovación desvela conflictos no resueltos de la sociedad argentina; no "re- 
mite a un pasado cristalizado quela evolución incesante de los acontecimientos históricos va dejando atrás" y, por lo tanto, permite "enriquecernos con nuevas experiencias de nuevas situaciones ahora más extremas" (Sebreli, 1971).

Y es que, en efecto, la imagen que nos da Santa Evita es que la muerte de la abanderada de los descamisados coincidió con el fin del poder de lo que el mismo Sebreli ha designado como "el ala plebeya del peronismo", el debilitamiento de la Central General de Trabajadores obrera y el surgimiento de la Central General de Empresarios y la claudicación - no sin resistencias, aunque su entrega del poder en 1955 sedio sin lucha ninguna- dePerón antela burguesía, las Fuerzas Armadas y el imperialismo.

Frente al sector populista de la burguesía desarrollista que trata de apropiarse de la figura deEvita, la novela deTEM rescata, entre otras, su imagen plebeya. Santa Evita muestra la lucha de clases - lo mismo sucede en la novela anterior-. La imagen que nos da no es la de una integración neutralizadora y despolitizada del fenómeno peronista y de Eva Perón. A ésta se la ve en relación vital con la realidad política y social: no es un mero objeto de contemplación, admiración y repudio, como lo son las grandes personalidades fuera de serie, sino que se la presenta dentro de contenidos ideológicos concretos en permanente pugna entre ellos. Así, la novela rescata el verdadero contenido histórico dela figura de Evita. Esto es, intentando el autor recuperar "Ia esencia mítica de un personaje central de la historia argentina" logra negar su musealización, su neutralización y despolitización. Cito nuevamente a Sebreli:

Contra la necrofilia de ciertos peronistas que reclaman la momia de Evita para convertirla en un objeto mágico de adoración mística, prefiero que la tumba de Evita siga abierta y que su tumba siga perturbando las conciencias.

Lo cumplido por TEM en Santa Evita - así nos parece- ha sido desacralizar el mito (atrevimiento suyo fue titular su obra como lo hizo: induce a creer que en ella la imagen de la figura histórica es unívoca, cuando, por el contrario, se la ofrece en toda su multivocidad). D esacralización tanto de su versión angélica como de su versión diabólica. Es así como ha hecho aflorar a la conciencia de sus lectores (sobre todo los más interiorizados y comprometidos con una definitiva visión):

que una severa censura interna y externa nos impone ocultar, es una de las maneras - la que corresponde al escritor más que al político- de contribuir al esclarecimiento de la conciencia de la clase trabajad ora y de las mujeres argentinas, o por lo menos de sus posibles dirigentes, de los cuadros, de quienes depende que la transformación social del país, el cambio histórico deje de ser 
un mito nostálgico en el que se proyectan las esperanzas y los sueños más ardientes de una gran parte del pueblo8.

TEM es escéptico con respecto a esa supuesta responsabilidad del escritor 0 , por lo menos, de la eficacia de su decir:

En verdad un libro, la literatura en general, por eficaz que sea, raramente contribuye a cambiar nada ni a que nadie tome conciencia de nada. Contribuye solamente a establecer un lento diálogo, a operar como un sedimento en la conciencia. Pero no a plazo inmediato, sino muy largo. Si uno piensa en la obra de Kafka, que tuvo que esperar más de treinta años para que se dieran las consecuencias de narraciones como La colonia penitenciaria en los campos de concentración. Ni la obra de Hemingway, ni la obra de Faulkner, ni la de Borges modifican nada en los imaginarios nacionales (C oddou y Figueroa, 2003: 339-350).

Pero, a pesar detales reticencias, no cabe duda de queTEM con sus obras ha logrado cambiar la imagen que tanto de Perón como de Evita se tenía. En La novela de Perón, "fue apareciendo un Perón que nadie había querido ver: no el de la historia sino el de la intimidad"9. Así como sabe que la Evita que hoy valoramos no es la misma que conocíamos antes de su propuesta imaginaria, hasta el punto de que pocos ahora dudan de que los hechos de las "zanjas ciegas" cubiertas por laficción no hayan sido verdaderos, real mente acontecidos. Q uien quiera saber sobre lo que pensó y sintió la muchachita ante la muerte de su padre o lo que ella le dijera al coronel Perón al conocerlo o el sentir de la Primera D ama ante las exigencias del pueblo a que aceptara la candidatura a la V icepresidencia en 1952, le basta leer lo que la novela le indica como hechos irredargüibles... Es así como TEM ha ido recreando el mito. C on datos ciertos de lo acontecido, hechos documentables y, sobre todo, con su poderosa imaginación que, por lo demás, no le es de propiedad exclusiva, pues atiende, con responsabilidad, como él mismo reconoce, "al imaginario y las tradiciones de la comunidad", a las que, tras apropiárselas, "les da vida de otro modo".

Cuando se le ha pedido esclarecer - y esto lleva, fatalmente, a una simplificación extrema- en qué consisteel mito deEvita, TEM ha respondido, enlazando su figura a las del Che Guevara y C risto:

\footnotetext{
${ }^{8}$ Esta larga cita constituye el párrafo de cierre del libro de Sebreli.

${ }^{9} \mathrm{Cfr}$. paratexto de la edición de la novela de Buenos Aires, Legasa, 1985.
} 
Latin American myths are more resistant that they seem to be. $N$ ot even the mass exodus of the Cuban raft people or the rapid decomposition and isolation of Fidel C astro's regimehad eroded thetriumphal myth of Che Guevara, which remains alive in the dreams of thousands of young people in Latin America, Africa and Europe. Che as well as Evita symbolize certain naive, but effective, beliefs: the hope for a better world; a life sacrificed on the altar of the desinherited, the humiliated, the poor of the earth. They are myths which somehow reproduce theimage of $\mathrm{Christ}^{10}$.

Y más adelante, en la misma respuesta que daba a quien le desafiara a re flexionar sobre el hecho dequesi antiguamente el imperial ismo se apropiaba de recursos como el cobre y el caucho, en el presente $\mathrm{H}$ ollywood se estaría apropiando de mucho más, de "los mismos mitos de su cultura nacional", el novelista responde:

The myth of the real Eva Perón will begin after the fires of the film have died down. Her image is al ready installed in history with such force and with as many lights and shadows as that of $\mathrm{H}$ enry the VIII, M arie Antoinette or JFK. The immortality of great personages begins when they become a methaphor with which people can identify. Evita is al ready several methaphors: she is the Robin $\mathrm{H}$ ood of the 20th century, sheisthe Cinderella of thetango and theSleeping Beauty of Latin America ${ }^{11}$.

Como puede verse con claridad, TEM tiene muy nítidas sus ideas acerca de lo que el mito de Evita representa, en toda su complejidad. Es por ello que puede proceder a su reformulación en una novela en que tal mito, según hemos dicho, se resemantiza y afirma.

\section{II}

TEM se instala y nosinstala en la realidad argentina a través de la configuración de su lenguaje narrativo, dando cumplimiento así a lo que M ichel Foucault ha señalado como la manera en que el hombre forja y reconoce su "real":

Los códigos fundamentales de una cultura - los que rigen sus lenguajes, sus esquemas perceptivos, sus cambios, sus técnicas, sus valores, las jerarquías de

10 Entrevista concedida por Tomás Eloy M artínez: "Evita or M adonna: whom will history remember? Interview with TEM", en N ew Perspectiva Quarterly, 1997, Vol. 14 № 1, pp. 32-34. Disponible en: http://www.las mujeres.com/evaperon/evitamadonna.shtml

${ }^{11}$ I bíd. Los subrayados, como en la cita anterior, son míos. 
sus prácticas- fijan de antemano para cada hombre, losórdenes empíricos con los cuales tendrá al go que ver y dentro de lo que se reconocerá (1968: 5).

Y es así como el escritor tucumano, en esas proposiciones de verdad sobre Perón, Evita y el peronismo, que constituyen sus novelas, deberesponder a todo un conjunto de condiciones bajo las cuales tales proposiciones van a estimarse precisamente como tales, como verdaderas. En ese conjunto de condiciones importan de sobremanera las presuposiciones. Según D ucrot y Lyotard los presupuestos deben ser verdaderos para que la proposición pueda ser considerada verdadera o falsa ${ }^{12}$. El carácter verdadero de una proposición se sostiene en la verificación ${ }^{13}$ y en la credibilidad del oyente, del lector. Presupone la intención de verdad (o engaño) en el emisor del discurso, como condición para que se cumpla el acto de comunicación. TEM insiste en que toda novela es mentira - "narrar significa licencia para mentir" es frase suya que hemos recordado- y, sin embargo, pretende que su lector acceda a la verdad de lo que se le narra. Es que la verdad puede guarecerse, enmascararse, en la mentira a través del amparo de la convención social. Cuando San Agustín sostieneque "mentir es decir lo contrario de lo que uno piensa, con la intención de engañar", está dando paso a la posibilidad de concebir mentiras lícitas, junto a las mentiras con intención de engañar (de perjudicar hablaba N ietzsche). Por otra parte la credibilidad, decíamos, hace que aceptemos con facilidad como verdad lo que son ciertas mentiras. TEM tenía una larga y reconocida carrera como periodista cuando escribió Santa Evita y había sido siempre fiel a su convicción de que en el periodismo es mandato ético el decir sólo la verdad. Esto es, la credibilidad de su palabra - de cualquier palabra suya- estaba garantizada por un prestigio establecido. Y como en su novela empleó las técnicas del periodismo, logró lo que no pretendía: que todo lo que allí cuenta fuera estimado verdadero. Pero lo decisivo es que la verdad que a él más le interesaba establecer quedó enmascarada en las mentiras de su ficción. Y esto no sólo por lo que hemos apreciado de su confianza en el poder de la imaginación para acceder a zonas recónditas de la realidad, sino porque también tiene como convicción suya de que la fabulación es una vertiente del lenguaje donde no sólo es posible, sino necesaria, la libertad:

\footnotetext{
${ }^{12} 0$ swald D ucrot, D ireet nepas di re (1972) y J.F. Lyotard, Le différend (1983). Ambos han visto en profundidad la función de la presuposición -noción propuesta por Gottlob Frege- en el habla. W ittgenstein en su Tractatus logi co phi losophicus (1975) sostiene que para poder decir: " $p$ " es verdadero (o falso), debo haber determinado en qué condiciones llamo verdadera a " $p$ ".

${ }^{13}$ Bertrand Russell ha señalado: "Cuando el enunciado se da primero y la evidencia después, hay un proceso que se llama verificación, que implica la confrontación de un enunciado y la evidencia" (1983: 83).
} 
Yo creo que la novela es el género de la libertad, y en esa medida cualquier confusión genérica es posible, cualquier elemento bastardo, marginal de la realidad es introducible en la novela (... ) Laúnica fidelidad del novelista es a sí mismo, a su propia libertad (N eyret, 2002: 19).

La lógica moderna - desde Frege y Russell a D ucrot y Van Dijk- ha probado que el lenguaje, al hablar de lo falso - su vertiente fabuladora- no atenta contra la lógica del lenguaje sino que atiende a su poder más legítimo: el de crear mundos alternativos en el mismo proceso de la tarea de designación. Lo que se ha considerado como creación de mundos posibles, un discurso que se libera de su compromiso directo con el referente al poner en escena las posibilidades de sentido. Cuando Foucault $(1974,1983)$ reflexiona que la verdad está allí no sólo para limitar una posibilidad creadora sino también para instaurar un poder, abre la opción a que se postule una vindicación del poder de lo falso, como Io hace $G$ eorge Steiner al señalar:

Lo falso no es, salvo en el sentido más formal o puramente sistemático, una falta de adecuación a los hechos. La facultad humana para enunciar cosas falsas, para mentir, para negar lo que es, está en el núcleo mismo del lenguaje y anima la reciprocidad entre las palabras y el mundo (1980: 246).

$M$ aurice Blanchot, por su parte, al señalar que el novelista - idea que acepta plenamente TEM - "es un hombre sometido por entero a la ley de verosimilitud" (1977: 203), nos está diciendo que la ficción tieneuna secreta aspiración a desprenderse completamente de las imposiciones de la verdad. Las postulaciones deTEM y su realización en las novelas permiten ver que las ficciones verdaderas - de esa índole son La novela de Perón y Santa Evita- poseen el poder de contestación a los regímenes de verdad, así como tiene el de desmitificar (en el sentido de que atentan contra el mito establecido) y de desenmascarar las verdades establecidas: se enfrenta, como sabemos, subversivamente a la historiografía oficial . Lo ha dicho Carlos Fuentes, en palabras... deTEM que él cita:

"M ito e historia se bifurcan y en medio queda el reino desafiante de la ficción". [TEM ] quiere darlea su heroína [Evita] una ficción porquela quiere, en cierto modo, salvar de la historia: "Si pudieramos vernos dentro de la historia -dice TEM -, sentiríamos terror. No habría historia porque nadie querría moverse". Para superar ese terror, el novelista nos ofrece, no vida, sólo relatos (Fuentes, 1996). 
D el escritor argentino podrían traerse a colación gran cantidad de afirmaciones que aluden precisamente a lo que considera $C$ arlos Fuentes con respecto a Santa Evita. Así, por ejemplo, en un ensayo medular suyo, sugerentemente titulado "M ito, historia y ficción: idas y vueltas". En él, citando obras "históricas" de Carlo Ginzburg, Robert D arnton y Philippe Aries y otras "ficcionales" de D. M . T homas y Julian Barnes, concluye que en ellas "la ilusión lo envuelve todo y el hielo de los datos va formando un solo nudo con el sol de la narración" (1996d: 109), y se pregunta, retóricamente:

¿Con qué argumentos negar a la novela, que es una forma no encubierta de ficción, su derecho a proponer también una versión propia dela verdad histórica? ¿C ómo no pensar que, por el camino de la ficción, de la mentira que osa decir su nombre, la historia podría ser contada deun modo también verdadero 0, al menos, tan verdadero de los documentos? (1996d: 119).

Con estas preguntas parece estar dando respuestas convincentes al inquirir de su maestro Barthes - TEM efectivamente fue discípulo del teórico y pensador francés- que cuestionaba:

La narración de los acontecimientos del pasado, que en nuestra cultura, desde los griegos en adelante, ha estado sujeta a la sanción de la "ciencia" histórica ligada al estándar subyacente de lo "real", y justificada por los principios de la exposición "racional", ¿difiere, en realidad, esta forma de narración, en algún rasgo específico, con alguna característica indudablemente distintiva, de la narración imaginaria, como la que encontramos en la épica, la novela o el drama? (1973: 22).

Es el mismo Barthes que en otro lado señal ara quela escritura también es un acto de solidaridad histórica, queriendo decir que hay que integrar la práctica del lenguaje como una dicotomía y una interacción entre texto y contexto histórico. Afirmación de la cual parece glosa, profundización y ampliación, lo sostenido por TEM en el ensayo suyo que hemos recién citado:

La ficción y la historia se escriben para corregir el porvenir, para labrar el cauce derío por el que navegará el porvenir, para situar el porvenir en el lugar de los deseos. Pero tanto la historia como la ficción se construyen con las respiraciones del pasado, reescriben un mundo que hemos perdido y, en esas fuentes comunes en las que abrevan, en esos espejos donde ambas se reflejan mutuamente, ya no hay casi fronteras: las diferencias entre ficción e historia se han ido tornando cada vez más lábiles, menos claras (1996d: 109). 


\section{REFERENCIAS}

Bajtín, M ijail. 1998. Estética de la creación verbal. M éxico: Siglo XXI.

Barthes, Roland et al. 1970. Análisis estructural del relato. Buenos Aires: Ed. Tiempo Contemporáneo.

Barthes, Roland. 1973. El grado cero de la escritura. Buenos Aires: Siglo XXI.

Blanchot, M aurice. 1977. Fal sos pasos. Valencia: PreTextos.

Brushwood, John S. 1975. TheSpanish American N ovel. A $20^{\text {th }}$ C entury Survey. Austin: U niversity of Texas Press.

Cancel, M ario. 1995. "Sobre la historia y la literatura: Una visión de conjunto", en A Gaztambide (comp.), H istoria y literatura, San Juan: Posdata, pp. 39-60.

Coddou, M arcelo y Ana Figueroa. 2003. "El vuelo dela reina o el viaje al otro lado del espejo. Entrevista a Tomás Eloy M artínez", en Alpha, №19, pp. 339-350, U niversidad de Los Lagos, 0 sorno.

Costa Lima, Luis. 1986. "Literatura e sociedade na América H ispánica (século XIX e comencos do século XX)", en Sociedade e discurso ficcional. Río de Janeiro: Ed. Guanabara.

Foucault, M ichel. 1968. Las palabras y las cosas. M éxico: Ed. Siglo XXI.

- - - - - . 1974. El orden del discurso. Barcelona: Tusquets.

- - - - - . 1983. La verdad y las formas jurídicas. M éxico: Gedisa.

Fuentes, Carlos. 1996. "Santa Evita", en suplemento Cultura del diario La Nación. Buenos Aires.

González Bermejo, Ernesto. 1971. Cosas de escritores. M ontevideo: M archa.

Genette, Gerard. 1987. FiguresI. Paris: Editions de Seuil.

Jameson, Fredric. 1981. The political unconscious. N arrative as socially simbolic act. N ew York: C ornell U niversity Press.

M artínez, Tomás Eloy. 1993. La novela de Perón. Barcelona: RBA Editores.

- - - - - . 1996a. Santa Evita. N ovela. BuenosAires: Ed. Planeta, 12ª ed. (1995).

- - - - - . 1996b, 5 de mayo. "Argentina entre la historia y la ficción", Página 12, Buenos Aires.

- - - - - . 1996c. "H istoria y ficción dos paralelos que se tocan", en K. Kohut (ed), Literaturas del río de La Plata hoy: De las utopías al desencanto. Frankfurt: Vervuert Verlag, pp. 90-100.

- - - - - 1996d. "M ito, historia y ficción: idas y vueltas", en Visiones cortazarianas. Historia, política y literatura hacia el fin del milenio. M éxico: Aguilar, pp. 109-133.

- - - - . 1998. "Ficción e historia en La novela de Perón". H ispamérica, № 17, pp. 41-49.

- - - - . 2004. "Ficción, historia, periodismo: límites y márgenes". (acceso: 261007). D isponible en: http://americat.net/docs/biblioteca/catedra/3\%20 catedra\% 20america\%20Eloy\%20mart.pdf.

M ora, M iguel. 2002. "Entrevista: Tomás Eloy M artínez-Escritura", en diario El País, 8 de noviembre.

N eyret, Juan Pablo. 2002. "N ovela significalicencia para mentir. Entrevista con TEM ", en Espéculo. Revista de estudios literarios, U niversidad Complutense de M adrid, № 22, pp. 18-26. 
Rama, Angel. 1982. La novela latinoamericana. Panoramas 1920-1980. Bogotá: Colcultura.

Russell, Bertrand. 1983. Significado y verdad. Barcelona: Ariel.

Sebreli, Juan José. 1971. Eva Perón: zaventurera o militante? Buenos Aires: Ed. La Pléyade, 4a. ed. ampliada.

Steiner, George. 1980. D espués de Babel. M éxico: F.C.E.

Vargas Llosa, M ario. 1969. "N ovela primitiva y novela de creación en América Latina". Revista de la U niversidad de M éxico, XXIII, N 010 , pp. 29-36.

W hite, H ayden. 1987. El contenido delas formas. Barcelona: Paidós. 
